\title{
Piscivore assemblages and predation pressure affect relative safety of some back-reef habitats for juvenile fish in a Caribbean bay
}

\author{
M. Dorenbosch ${ }^{1,2, *}$, M. G. G. Grol ${ }^{1}$, A. de Groene ${ }^{1}$, G. van der $\operatorname{Velde}^{1,2}$, \\ I. Nagelkerken ${ }^{1, * *}$
}

${ }^{1}$ Department of Animal Ecology and Ecophysiology, Institute for Wetland and Water Research, Faculty of Science, Radboud University, Heyendaalseweg 135, PO Box 9010, 6500 GL Nijmegen, The Netherlands

${ }^{2}$ National Natural History Museum Naturalis, PO Box 9517, 2300 RA Leiden, The Netherlands

\begin{abstract}
An important process thought to drive habitat selection during (post-)settlement of coral reef fish is predation. It is assumed that in back-reef habitats such as seagrass beds and mangroves predation is lower than on coral reefs. However, recent studies have suggested that significant piscivore assemblages are present in back-reef habitats. The assumption of reduced predation pressure in back-reef habitats can therefore be debated. We compared piscivore assemblages along the coast of a Caribbean island using underwater visual census surveys in a spatial gradient of coral reefs, seagrass beds and mangroves. We also performed predation experiments in combination with video observations in these habitats using tethered recently settled Haemulon flavolineatum. High piscivore densities and reduced survival showed the presence of significant piscivore assemblages in both reef and back-reef habitats. Both reef-associated piscivores and piscivores that use back-reef habitats as a juvenile habitat contributed to the piscivore assemblage in the investigated gradient. Habitat type had a significant effect on the composition of the piscivore assemblage, density, and prey survival. Piscivore density was highest on the reef, mangroves and notches, all of which are habitats with a high structural complexity. On the contrary, seagrass beds showed lowest piscivore density. Tethering experiments showed lowest survival on the reef but also reduced survival on backreef habitats located close to the coral reef. Seagrass beds and mangroves located farther away from the reef into the bay showed highest survival. The present study shows that the concept of reduced predation in back-reef habitats used by juvenile fish does not apply to all habitats, since these habitats can harbour significant piscivore assemblages. However, depending on the spatial setting in the seascape (distance to the reef and presence of other habitat types), some Caribbean seagrass beds show low densities of piscivores and increased survival when compared to other habitats.
\end{abstract}

KEY WORDS: Coral reef fish $\cdot$ Predation $\cdot$ Seagrass beds $\cdot$ Mangroves $\cdot$ Nursery $\cdot$ Habitat configuration Resale or republication not permitted without written consent of the publisher

\section{INTRODUCTION}

Predation on early recruits of marine fish is considered an important mechanism that structures species assemblages in tropical shallow water habitats by reducing densities and influencing size distributions as well as affecting competition (Hoey \& McCormick 2004, McCormick \& Hoey 2004, Hixon \& Jones 2005,
Almany \& Webster 2006). Many species of coral reef fishes may reduce post-settlement mortality from predation by 2 strategies. (1) Recently settled recruits on coral reefs may have an adaptive growth strategy. Individuals with higher growth rates or compensatory growth show higher survival because predation on coral reefs is concentrated on the smaller recruits (Vigliola \& Meekan 2002, Hoey \& McCormick 2004, 
Holmes \& McCormick 2006, Gagliano \& McCormick 2007). (2) Recruits may avoid predation on coral reefs by direct settlement into back-reef habitats located away from the coral reef, such as seagrass beds and mangroves (Watson et al. 2002, Arvedlund \& Takemura 2006, Pollux et al. 2007). Back-reef habitats are thought to have a lower predation pressure and thus a higher post-settlement survival of small juvenile fish (Beets 1997, Dahlgren \& Eggleston 2000). In combination with other factors that increase growth and survival, such as high food availability, high water temperature and refuge from physical disturbance (Blaber 2000, Beck et al. 2001), shallow water habitats such as seagrass beds and mangroves are attractive habitats for juvenile coral reef fishes. After spending their juvenile life phase in these habitats, these fishes may replenish the adult population on a coral reef via ontogenetic migration (Verweij et al. 2008). When the per capita production of juveniles from these habitats to the adult stock population is higher than from other habitats, these habitats function as nurseries (Beck et al. 2001).

Decreased predation pressure is frequently mentioned as an explanation for the high juvenile fish densities in back-reef habitats (e.g. seagrass beds and mangroves). However, there is no consensus with respect to this assumption. Various studies that have indicated lower predation pressure in seagrass beds and/or mangroves also showed substantial variation in predation, suggesting predation may be confounded with other effects such as complexity and spatial configuration of the habitat (Shulman 1985, Nakamura \& Sano 2004, Chittaro et al. 2005). Eggleston et al. (1997) and Almany (2004) demonstrated that predation of small fish on coral reefs may be reduced by the protective capacity provided by the structural complexity of the reef. Relatively high densities of piscivores can occur in shallow estuaries, suggesting that predation in back-reef habitats may be considerably higher than generally assumed (Nakamura \& Sano 2004, Baker \& Sheaves 2005, Kulbicki et al. 2005, Baker \& Sheaves 2006, Baker \& Sheaves 2007). However, no studies have assessed the assemblage and density of predators in a coral reef-seagrass-mangrove seascape in combination with experimental assessment of survival. Therefore, in this study we combined measurements of predator assemblages and densities in multiple habitats with experiments of tethered fish that assessed relative survival across a gradient of back-reef to nearshore reef habitats.

Although high selective mortality of juvenile fish from predation has predominantly been reported from coral reefs, we hypothesize that predation pressure on small juvenile fish in back-reef habitats may be significant, and possibly similar to predation pressure on the coral reef. Back-reef habitats may border coral reefs, which facilitates entry of reef-associated piscivores to these non-reef habitats for feeding (Baker \& Sheaves 2007, Dorenbosch et al. 2007, Valentine et al. 2007). Aside from this, back-reef habitats located farther away from the coral reef may harbour resident populations of piscivores (Baker \& Sheaves 2005), including larger juvenile piscivorous fish (Eggleston et al. 2004). Within these back-reef habitats, structurally complex habitats, such as rocks and mangroves, may concentrate fish, including piscivores. This could result in differences in predation risk on small juvenile fish among back-reef habitats, and subsequently lead to habitat segregation of size classes (Mittelbach \& Chesson 1987). To investigate the existence of differences in predation pressure between shallow-water habitat types in the field, the following questions were addressed: (1) Is piscivore density and predation risk for small juvenile coral reef fishes after settlement influenced by shallow water habitat type and distance to the coral reef? (2) How does the composition of piscivore species assemblages and size structure distribution change in a gradient of back-reef to coral reef habitats?

\section{MATERIALS AND METHODS}

Study area and study sites. The present study was conducted in the southern Caribbean Sea on the island of Curaçao, Netherlands Antilles (Fig. 1). Twelve study sites were selected on the leeward side of the island in Spanish Water Bay and on the adjacent coral reef (Fig. 1). Spanish Water Bay is a sheltered marine bay connected to a fringing coral reef by a narrow entrance channel (water depth $\sim 15 \mathrm{~m}$ ) that opens into a wide and shallow bay area. Within the bay, seagrass beds are present together with stands of mangroves. In areas where the shore consists of a fossilized limestone plateau, rocks, notches and crevices characterize the shoreline of the bay. The entrance of the bay consists of a large sandy plateau (water depth $\sim 6 \mathrm{~m}$ ), lined by degraded reef and rubble. In front of the bay is a continuous fringing coral reef consisting of a reef flat (water depth $\sim 5 \mathrm{~m}$ ) that steeply drops off at a water depth of $\sim 8 \mathrm{~m}$.

Tidal range in the area is $\sim 30 \mathrm{~cm}$ and only weak tidal currents are present; all habitats stay inundated during the tidal cycles with a minimum water depth of $\sim 50 \mathrm{~cm}$ during low tide (mangroves and notches). Influence of the tidal cycles on the results of the present study are therefore considered very low. Mean water temperature in the study period (August to November 2005) was $28.7^{\circ} \mathrm{C}$ on the reef and $30.9^{\circ} \mathrm{C}$ in the bay, mean salinity was 33.9 on the reef and 34.5 in the bay, underwater visibility ranged between 15 and $33 \mathrm{~m}$ (horizontal Secchi disk distance) on the reef (mean $28.3 \mathrm{~m}$ ) and between 3 and $14 \mathrm{~m}$ in the bay (mean $6.7 \mathrm{~m}$ ). 


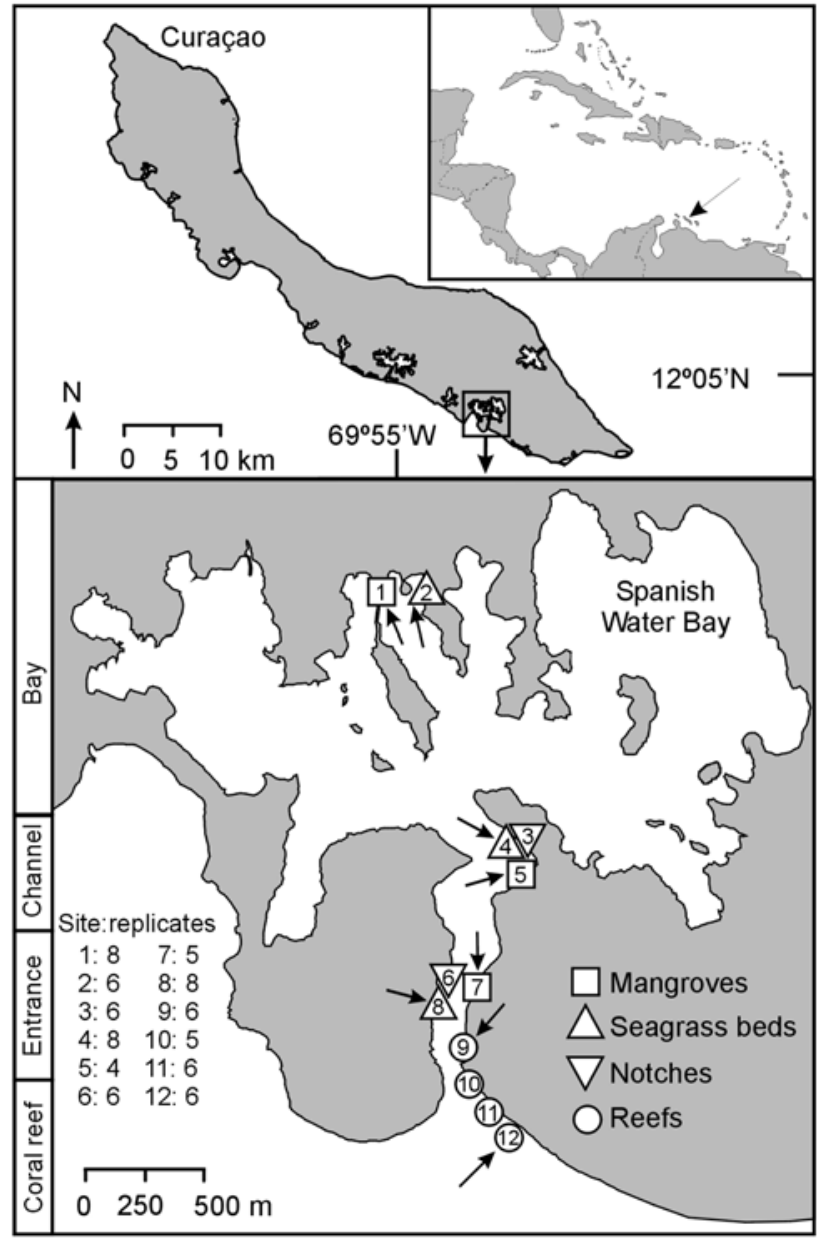

Fig. 1. Island of Curaçao and the 12 study sites in Spanish Water Bay. Study sites are located in a $2500 \mathrm{~m}$ distance gradient with respect to the reef (see 'Materials and methods'): bay (sites 1-2), channel (sites 3-5), entrance (sites 6-10) and fringing coral reef (sites 11-12). Arrows indicate sites where predation experiments were conducted. Site:replicates show each site (number) and the number of replicate transects for predator density counts

In a $2500 \mathrm{~m}$ gradient stretching from the fringing coral reef to the center of the bay, 12 study sites were selected, representing all major shallow water habitat types of the study area (Fig. 1): seagrass beds $(\mathrm{n}=3)$, mangroves $(\mathrm{n}=3)$, notches, crevices and rocks (hereafter referred to as notches, $\mathrm{n}=2$ ), and coral reefs ( $\mathrm{n}=$ 4). Seagrass beds consisted of monospecific beds of Thalassia testudinum with $100 \%$ canopy cover whereas mangroves stands consisted of Rhizophora mangle with a dense prop root system. Water depth of seagrass beds, mangroves and notches was $\sim 1 \mathrm{~m}$. Two reef sites (depth $\sim 3 \mathrm{~m}$ ) were located in the entrance of the bay on a sandy slope and were characterized by low live coral cover (average $5 \%$ ) and dominated by rubble and degraded hard corals. The 2 other reef sites (depth $\sim 5$ to $8 \mathrm{~m}$ ) were located outside the bay and were connected to the continuous fringing coral reef along the coast of Curaçao; live coral coverage at these 2 sites (average $41 \%$ ) was considerably higher than at the 2 reef sites in the entrance of the bay. Water depth of reef sites ranged between 3 and $5 \mathrm{~m}$.

The sites selected are located in an area of Spanish Water Bay in which previous work has shown high densities of juvenile fish in seagrass beds, mangroves, notches and the shallow coral reef (Nagelkerken et al. 2000a, Cocheret de la Morinière et al. 2002, Pollux et al. 2007). Depending on the species, densities of small juvenile fish $(<7.5 \mathrm{~cm})$ were high in either the coral reef in front of the bay, habitats in the entrance of the bay or the centre of the bay. It is assumed that shallow water habitats in the bay function as an important habitat for juveniles of some fish species that use the coral reef as an adult habitat.

Visual census of piscivore assemblages. To identify the fish species assemblages, densities and sizes of potential piscivores, we conducted underwater visual census surveys at all study sites using belt transects as used by Nagelkerken et al. (2000a). All fish species for which fish is part of the diet (see references in 'Data analyses and statistics') and other potential predators (e.g. squid, octopus) were recorded during the surveys. Visual census surveys were conducted by 2 independent observers using SCUBA at sites with a water depth $>1 \mathrm{~m}$, whereas snorkeling gear was used at shallower sites (seagrass beds, mangroves, notches). Observers were well trained with respect to visual census methodology (i.e. species identification and estimation of numbers and sizes of fish) a priori to surveys. Transect size was $25 \times 4 \mathrm{~m}$ at all sites with the exception of notches $(25 \times 3 \mathrm{~m})$ and mangroves $(10 \times$ $2 \mathrm{~m}$ ), where spatial complexity allowed only smaller transects. The submersed prop root system of the mangroves was on average $2 \mathrm{~m}$ wide. Due to relatively clear water (underwater visibility $>3 \mathrm{~m}$ ), fishes hiding in the root system of the mangroves could be well detected during the visual census surveys. Permanent transects were placed randomly at each site and the number of replicate transects per site varied between 4 and 8 , depending on the surface area of the habitat. The number of transects per site is listed in Fig. 1. The sequence of transects that were surveyed each time at each site was random. Minimum distance between replicate transects was $12.5 \mathrm{~m}$. Five independent visual census surveys were performed in each transect from August to November 2005, between 09:00 and 13:00 $\mathrm{h}$. Time between surveys ranged from 3 to $12 \mathrm{~d}$. Since predation may also be significant at night (Danilowicz \& Sale 1999) and the piscivore assemblage may be underestimated by merely conducting surveys during the day (Unsworth et al. 2007), all transects were also surveyed once at night to obtain information 
on the structure of the piscivore assemblage at night. Surveys performed at night started $1 \mathrm{~h}$ after sunset, when the period of twilight migrations of fishes ended. At night, transects were carefully searched with a high intensity underwater torch according to Nagelkerken et al. (2000b).

All potential piscivores were identified underwater and size (total length, TL) of each fish was estimated to the nearest $\mathrm{cm}$. Underwater estimation of fish size was intensively trained simultaneously by the observers prior to the surveys.

Predation experiments. In addition to the visual census surveys of the piscivore assemblages of the study sites, we conducted predation experiments at 8 sites along the gradient to study differences in predation pressure among habitats (Fig. 1): seagrass beds $(n=3)$, mangroves $(n=3)$, and reefs $(n=2)$. Experiments were conducted by examining removal of 203 tethered juvenile Haemulon flavolineatum by predators in 90 min time periods. In total, $74 \mathrm{H}$. flavolineatum were tethered on seagrass beds, 80 in mangroves, and 49 on the reefs in the entrance and outside the bay (see Table 2). Removal experiments of tethered fish are regularly used to measure mortality by predation of coral reef associated fish (Shulman 1985, Danilowicz \& Sale 1999, Dahlgren \& Eggleston 2000, Chittaro et al. 2005). Because $H$. flavolineatum occurs in high densities in the bay habitats (Nagelkerken et al. 2000a) and also uses the reef as a juvenile habitat (Dorenbosch et al. 2004), it is suitable as a prey fish model species.

For the tethering experiments we used the smallest available juveniles of recently settled Haemulon flavolineatum. Selected fish ranged between 3.1 and $4.5 \mathrm{~cm}$ (TL, mean $4.2 \mathrm{~cm}$ ) and were all characterized by early juvenile body coloration pattern. Consequently, fish used in the experiments all represented the early juvenile life stage after settlement. All juveniles were caught by a stationary trap net at a single location in the entrance of the bay. The time between capture of juveniles and the start of tethering experiments was on average $1 \mathrm{~h}$. By using a thin needle, each fish was attached through its lower jaw to a $50 \mathrm{~cm}$ monofilament line (diameter $0.2 \mathrm{~mm}$ ) anchored to the substratum by an iron pole. Removal of tethered fish by piscivores or other predators was visually checked at 10 min intervals by an observer (with snorkeling gear in seagrass and mangrove habitats, SCUBA in reef habitats) for a period of $90 \mathrm{~min}$. During the $90 \mathrm{~min}$ period, the observer waited at a distance of $\sim 50 \mathrm{~m}$ from the experimental location and approached each tethered fish very briefly with a minimum distance of $\sim 5 \mathrm{~m}$ after each $10 \mathrm{~min}$ interval to verify whether the fish had been consumed, was dead, or was alive and still active. Although this methodology may cause disturbance to predators, the procedure could be standard- ized very well for all sites. Since water clarity was high on the coral reef, disturbance may have been stronger there compared with habitats located in the bay; however, prior to the experiments, the method was extensively practised and evaluated during pilot studies on the coral reef $(n=20)$ and seagrass beds $(n=20)$. These pilots showed that tethered fishes were not able to break the tether line. A broken tether line was therefore considered as removal by a predator. Although the presence of an observer resulted in some disturbance of the fish community, most piscivores (such as Aulostomus maculatus, Epinephelus striatus, Lutjanus apodus and Sphyraena barracuda) returned rapidly (within $1 \mathrm{~min}$ ) and behaved naturally. During the pilot studies, the behavior of the tethered fishes was observed carefully. Tethered fishes did not behave naturally (e.g. resting in schools) but showed a continuous active swimming behavior. However, this behavior was similar among individuals and habitats, and swimming continued during the entire $90 \mathrm{~min}$ period. Experiments were conducted at water depths $>1 \mathrm{~m}$. Structural complexity within each habitat type (i.e. with respect to shelter for tethered fishes) was comparable among sites and within a site; tethering experiment locations were located randomly at each site.

A prey removal experiment was considered successful when the fish behaved actively (i.e. showing swimming behavior) during the entire 90 min period or until the moment of removal by a predator. When tethered fish were dead or inactive close to the substrate, experiments were not included in the data set. In total, 253 fish were tethered, of which 203 trials were considered successful experiments. The number of successful experiments varied per site and is listed in Table 2. Various experiments were conducted simultaneously at each site with a maximum of 8 ind. in one $90 \mathrm{~min}$ period. Minimum distance between experiments was $10 \mathrm{~m}$. Predation experiments were run within the same timeframe as the visual census surveys (between 09:00 and 13:00 h).

In addition to the visual observations, $40 \%$ of the performed predation experiments were recorded continuously (90 min) by an underwater video camera on a tripod at a distance of $\sim 3 \mathrm{~m}$ from the tethered fish to verify and identify removal of tethered fish by predators. Video observations were performed in all habitats. In total, 33 removals recorded by the video camera could be used for this purpose.

Data analyses and statistics. Foraging strategies differ greatly among piscivorous fish species, resulting in different diets. Some species feed entirely on fish; for other species fish is only part of their diet. Various species show an ontogenetic shift from zoobenthos and/or zooplankton feeding to fish feeding during their life cycle. We therefore investigated 3 diet classes for 
the piscivore assemblage: highly specialized piscivores (high piscivores), moderately specialized piscivores (moderate piscivores), and lowly specialized piscivores (low piscivores, Appendix 1). High piscivores depend entirely on fish feeding during their entire lives (75 to $100 \%$ of diet). Moderate piscivores frequently have fish in their diet (25 to $75 \%$ of diet), but also feed on other prey items such as zooplankton and zoobenthos. Low piscivores normally feed on other prey items, but occasionally also feed on fish (in general $<25 \%$ of diet). Diet data was derived from the following studies: Rooker 1995, Duarte \& Garcia 1999, St John 1999, Nagelkerken et al. 2000b, Marnane \& Bellwood 2002, Cocheret de la Morinière et al. 2003a,b, Kamukuru \& Mgaya 2004, Baker \& Sheaves 2005, Froese \& Pauly 2005, Kulbicki et al. 2005. For various species of piscivores, a clear ontogenetic diet shift is known to occur at specific lengths (Appendix 1). Individuals observed in the present study with a TL below the size for which fish have been found to be part of the diet were considered non-piscivores and omitted from piscivore data analyses.

Optimal predator-to-prey size varies with species and predator size. In general, as predators grow, they prefer larger prey. However, some predator species shift their prey preference towards smaller prey as they grow (Floeter \& Temming 2005). Scharf et al. (2000) and Kulbicki et al. (2005) demonstrated that larger piscivores can prey more efficiently on small juvenile fish than can smaller piscivores. Therefore, both small and large piscivores may be effective predators on small juvenile fish. In addition to the effect of diet type, we also investigated the effect of predator size on the composition of the total piscivore assemblage. The piscivore assemblage at each site was therefore divided into 4 size classes representing increasing predator-to-prey size ratios: 5 to $15 \mathrm{~cm}$ (predator-to-prey size ratio from 1.2 to 3.6), 16 to $30 \mathrm{~cm}$ (3.8 to 7.1 ), 31 to $45 \mathrm{~cm}$ (7.4 to 10.7$),>45 \mathrm{~cm}$ (>11.0). These predator-to-prey size ratios were calculated a priori to data analysis and were based on the mean length $(4.2 \mathrm{~cm})$ of tethered juvenile Haemulon flavolineatum. The smallest observed piscivore was $5 \mathrm{~cm}$.

For each piscivore species, the mean density per transect was calculated based on the 5 surveys conducted during daytime. For each transect, a mean species richness was calculated based on the total species counts during the 5 surveys. For nighttime, data were only available for 1 survey. Subsequently, for each habitat type, mean total piscivore density and mean species richness was determined for the entire piscivore assemblage (all species pooled, transects as replicates). Additionally, mean total piscivore density was calculated for the 3 diet classes (all species pooled per diet class, transects as replicates) and the 4 size classes (all species pooled per size class, transects as replicates).

Similarity in the piscivore assemblage structure among the investigated sites in the gradient was calculated using cluster analysis of piscivore species densities (per site, all size classes pooled, transects as replicates), using the BioDiversity Pro computer program (McAleece 1997) on basis of Bray-Curtis distances and using group average linkage with $\log _{10}$ transformed mean species densities.

The effect of habitat type and location of a site in the investigated gradient (hereafter referred to as site) on mean total piscivore density and mean total species richness per habitat type was tested with separate 2-way ANOVAs for day and night data. An additional 2-way ANOVA was performed to simultaneously investigate the effect of habitat type and site on mean total piscivore density during day and night. In the latter ANOVA, densities during day and night were set as the 2 dependent variables. For all analyses, site was set as a random factor that was nested within habitat. The 4 habitat types were set as a fixed factor and transects were treated as independent replicates (see Table 1).

The effect of habitat type and site on total piscivore density of the 3 diet classes and 4 size classes was investigated using 1-way analyses of covariance (ANCOVAs). These analyses were only performed for the daytime data. When using single transects as replicates for the different diet and size classes, many transects had 0 counts, which violated parametric assumptions. Therefore transects were averaged per site. The 4 habitat types were set as a fixed factor and site averages were treated as independent replicates. The effect of the distance of a site towards the coral reef on the piscivore assemblage of each site was determined by using the distance $(\mathrm{m})$ of each site to the coral reef (the shortest distance fishes had to swim to reach the start of the fringing coral reef) as a covariable. ANCOVAs are summarized in Table 1.

For all analyses, assumptions for normality were checked by residual analysis and spread versus level plots, homogeneity of variances was checked by means of a Levene's test. Data for all ANOVAs and ANCOVAs was $\log _{10}$ transformed to increase normality. Post-hoc comparisons were performed using Hochberg's GT2 tests for 2-way ANOVAs and Sidak's tests for 1-way ANCOVAs.

Independent linear regressions were used to further analyse the relationship between distance between a site and the coral reef, and mean total piscivore density during day and night, mean total species richness, and mean total density of the 3 diet classes and 4 size classes, respectively. For each regression either one of 
the variables listed above was set as the dependent variable, whereas distance of each site to the coral reef was set as the independent variable.

Prey removal data from the predation experiments was analyzed with a Kaplan-Meier survival analysis. This procedure compares survival and removal times of tethered fish among habitats based on censored and complete data. Removal of a tethered fish is considered as a complete observation, while a censored observation refers to a fish that survives the 90 min experiment time. Both overall comparison and pair-wise comparisons among the 8 investigated sites were made using the Breslow procedure, based on a generalized Wilcoxon test.

For 8 sites both survival data and data on mean total density of the piscivore assemblage were available. The effect of habitat type and distance of a site to the coral reef on prey removal efficiency and mean total piscivore density was analyzed using a 2-way ANCOVA (summarized in Table 1). Mean total piscivore density and survival (based on the tethering experiments at a site) were set as the 2 dependent variables. The 8 sites were used as replicates. Mean total piscivore density was calculated based on all transects per site. Habitat was set as a fixed factor. Distance of each site to the coral reef was set as a covariable. Data for the 2-way ANCOVA was $\log _{10}$ transformed to increase normality. All analyses described above were performed using SPSS version 14.0 .

\section{RESULTS}

\section{Piscivore assemblages}

During the visual census surveys, 32 fish species were classified as piscivores (Appendix 1). Although other potential predators, such as Cephalopoda, occur on the reefs of Curaçao, these were not observed during the surveys. Based on diet, 8 fish species were distinguished as high piscivores, 13 as moderate piscivores, and 11 species as low piscivores (Appendix 1). This piscivore assemblage showed a spatial distribution along the studied gradient in which 3 species groups could be distinguished (Appendix 1). Eight species occurred exclusively in habitats in the bay or both in the bay and entrance, 10 species occurred exclusively on the reef, in the entrance or in both, while 14 species occurred along the entire gradient.

Cluster analysis of piscivore assemblages showed a distinction primarily among assemblages based on habitat type (Fig. 2). Notches and mangroves (characterized by high densities of piscivores), and seagrass beds in the entrance and channel (characterized by low densities of piscivores) showed separated clusters. Also the 2 fringing coral reefs in front of the bay clustered together, whereas the reef in the entrance formed a separate cluster. The cluster containing the seagrass bed in the centre of the bay and the reef located further in the entrance of the bay formed an exception. Piscivore assemblages of these 2 sites were

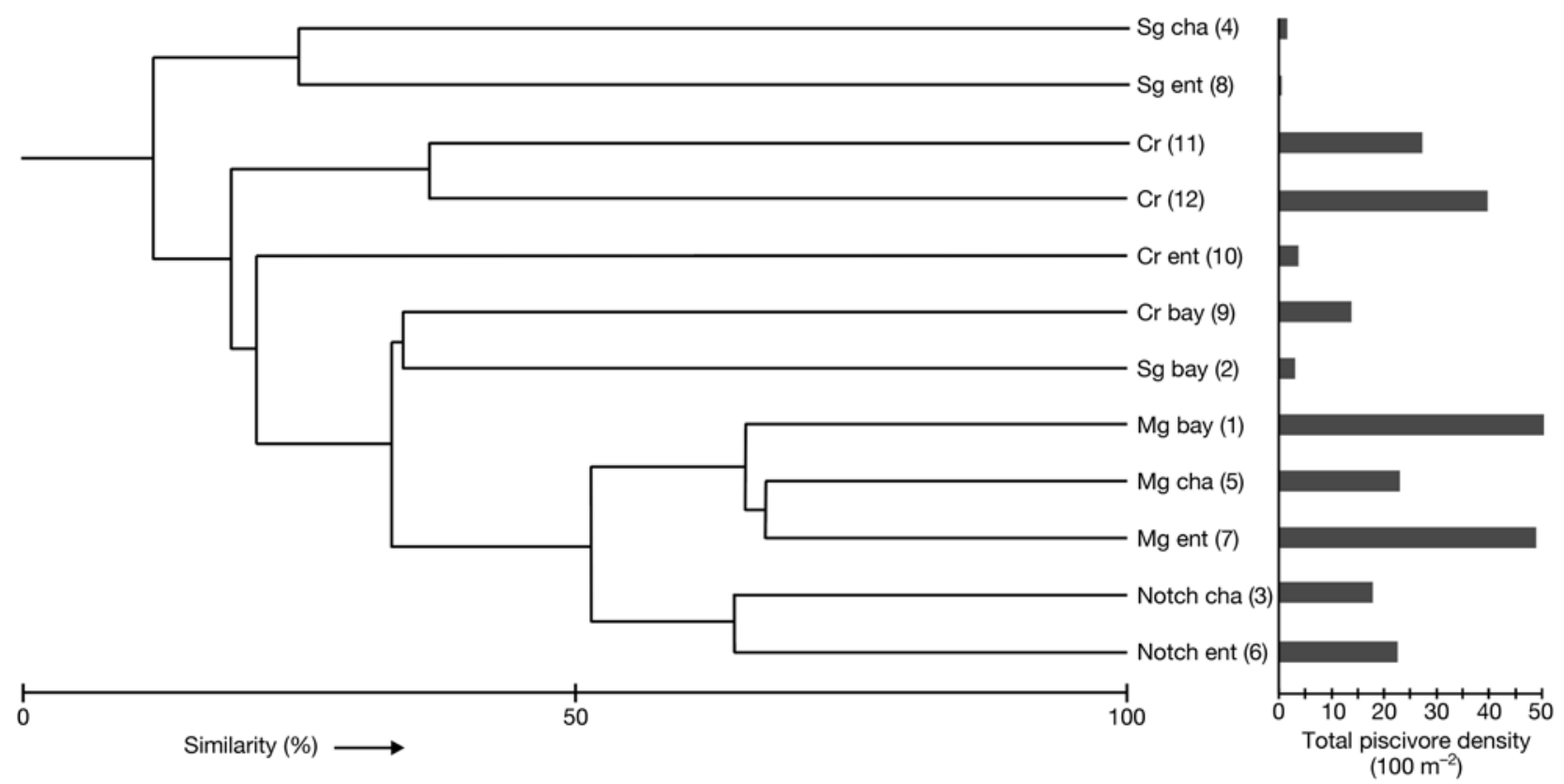

Fig. 2. Cluster analysis of the piscivore assemblage (32 species) from the 12 sites in the gradient. Bray-Curtis similarity and the group average linkage method were used to cluster $\log _{10}$-transformed mean species densities. For each site, mean total piscivore density during daytime is shown; numbers in parentheses indicate site numbers listed in Fig. 1. Cr: coral reef, Sg: seagrass beds, Mg: mangroves, Notch: notches, cha: channel, ent: entrance 
Table 1. Overview and results (p-values) of ANOVAs and analyses of covariance (ANCOVAs) conducted in the present study. Habitat: habitat type; site: site location in gradient; distance: distance of site to coral reef. NS: not significant

\begin{tabular}{|c|c|c|c|c|c|c|}
\hline \multirow[t]{2}{*}{ Analysis type } & \multirow[t]{2}{*}{ Main factor } & \multirow{2}{*}{$\begin{array}{l}\text { Nested factor/ } \\
\text { covariable }\end{array}$} & \multirow[t]{2}{*}{ Dependent variable(s) } & \multirow[t]{2}{*}{ Data } & \multicolumn{2}{|c|}{ Results (p-values) } \\
\hline & & & & & Main factor & $\begin{array}{l}\text { Nested factor } \\
\text { /covariable }\end{array}$ \\
\hline \multirow[t]{2}{*}{ 2-way ANOVA } & Habitat & Site $^{a}$ & Total density piscivores & Day & $<0.001$ & $<0.001$ \\
\hline & & & Species richness piscivores & Day & $<0.001$ & $<0.001$ \\
\hline \multirow[t]{2}{*}{ 2-way ANOVA } & Habitat & Site $^{\mathrm{a}}$ & Total density piscivores & Night & $<0.001$ & $<0.001$ \\
\hline & & & Species richness piscivores & Night & $<0.001$ & $<0.001$ \\
\hline \multirow[t]{2}{*}{ 2-way ANOVA } & Habitat & Site $^{\mathrm{a}}$ & Total density piscivores & Day & $<0.001$ & $<0.001$ \\
\hline & & & Total density piscivores & Night & $<0.001$ & $<0.001$ \\
\hline 1-way ANCOVA & Habitat & Distance $^{\mathrm{b}}$ & Total density high piscivores & Day & 0.033 & NS \\
\hline 1-way ANCOVA & Habitat & Distance $^{b}$ & Total density moderate piscivores & Day & 0.011 & NS \\
\hline 1-way ANCOVA & Habitat & Distance $^{\mathrm{b}}$ & Total density low piscivores & Day & NS & NS \\
\hline 1-way ANCOVA & Habitat & Distance $^{b}$ & Total density piscivores $0-15 \mathrm{~cm}$ & Day & $<0.001$ & NS \\
\hline 1-way ANCOVA & Habitat & Distance $^{\mathrm{b}}$ & Total density piscivores $16-30 \mathrm{~cm}$ & Day & 0.050 & NS \\
\hline 1-way ANCOVA & Habitat & Distance $^{\mathrm{b}}$ & Total density piscivores $31-45 \mathrm{~cm}$ & Day & 0.015 & 0.013 \\
\hline 1-way ANCOVA & Habitat & Distance $^{\mathrm{b}}$ & Total density piscivores $>45 \mathrm{~cm}$ & Day & 0.028 & 0.001 \\
\hline \multirow[t]{2}{*}{ 2-way ANCOVA } & Habitat & Distance $^{b}$ & Total density piscivores & Day & 0.011 & NS \\
\hline & & & Survival tethered fishes & Tethering & NS & NS \\
\hline
\end{tabular}

most similar to each other predominantly based on comparable relative densities of Caranx latus, Haemulon parra, Lutjanus apodus, L. griseus, and Ocyurus chrysurus (Appendix 1).

\section{Piscivore densities and habitat types}

The variables habitat type and site (nested within habitat type) showed highly significant effects for the mean total piscivore density and species richness during daytime (2-way ANOVA, Table 1). During the day, total piscivore density (Fig. 3a) and species richness (Fig. 3b) were significantly highest in the mangroves and lowest on the seagrass beds. Comparable to daytime, habitat type and site showed highly significant effects for the mean total piscivore density and species richness at night (2-way ANOVA, Table 1). During the night seagrass beds, as well as mangroves, showed significantly lowest piscivore densities (Fig. 3a). Piscivore species richness was significantly lowest in seagrass beds, but no difference was found among mangroves, notches and reefs (Fig. 3b). When total piscivore densities during day and night were compared simultaneously in an additional 2-way ANOVA, both habitat type and site also showed highly significant effects for total piscivore density during day and night (Table 1).

As for total piscivore densities, mean densities of high, moderate, and low piscivores were lowest on seagrass beds (Fig. 4). However, significant effects of habitat type were only observed for high and moderate piscivores (1-way ANCOVA, Table 1). For both high and moderate piscivores, seagrass beds showed signif-
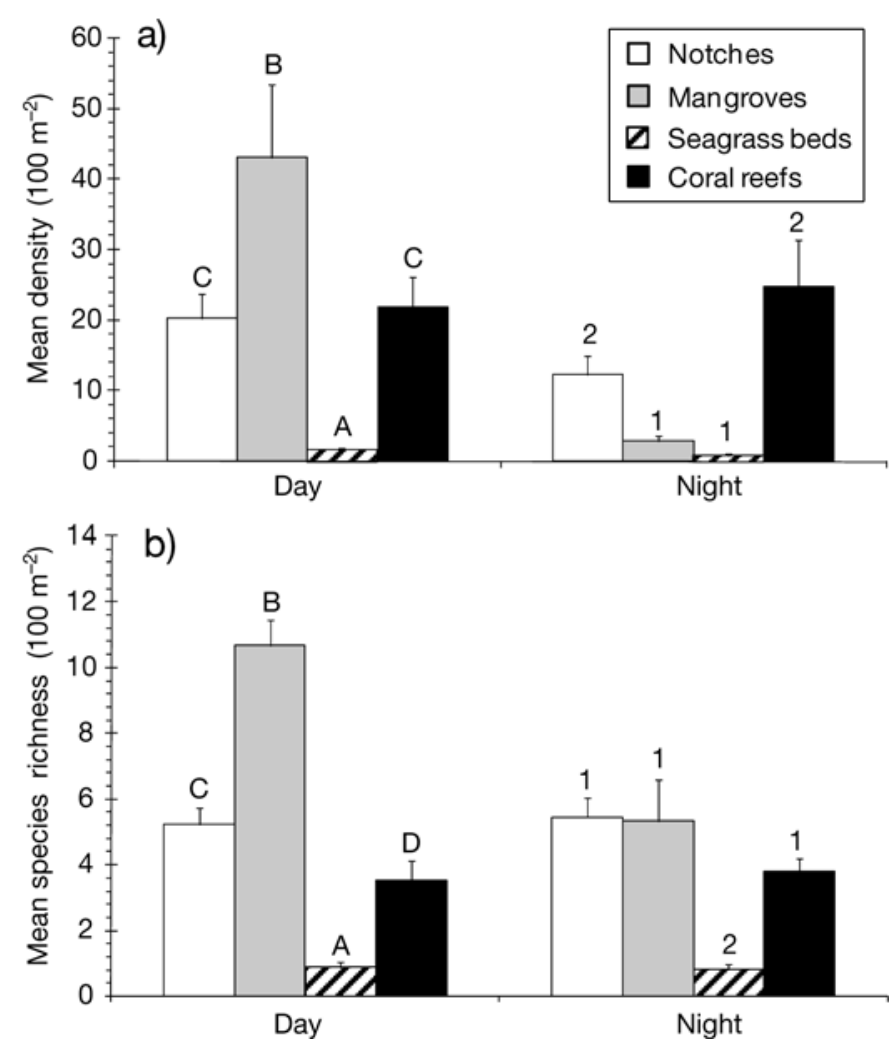

Fig. 3. Mean (+SE) total piscivore fish density (a) and species richness (b) of habitat types during day and night. Effect of habitat type and site (nested within habitat type) on fish density or species richness (see 'Materials and methods') was tested on day and night data separately by 2-way ANOVAs (Table 1). Within each graph, different letters (daytime) or numbers (nighttime) among habitat types indicate significant differences (Hochberg's GT2 post-hoc comparison, p < 0.05) 


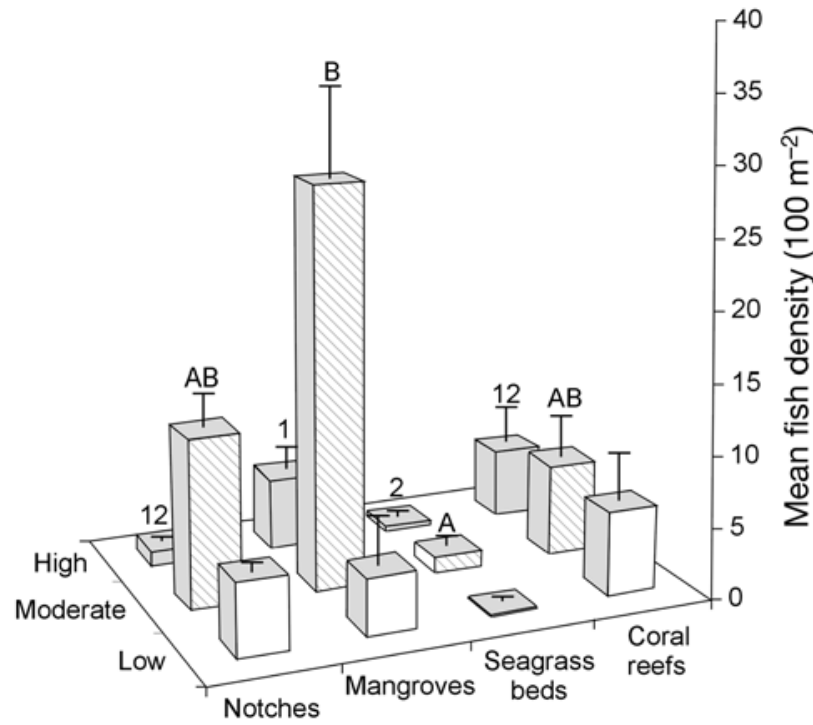

Fig. 4. Mean (+SE) density distribution of the piscivore assemblage in the 4 habitat types during daytime classified into 3 diet classes (high, moderate, and low piscivores, see 'Materials and methods' and Appendix 1). The effect of habitat type (main factor) and distance to the coral reef (covariable) on piscivore density was tested for each diet class separately by 1-way analysis of covariance (Table 1). Different letters (moderate piscivores) and numbers (high piscivores) among habitat types indicate significant different fish densities (Sidak's post-hoc comparison, $\mathrm{p}<0.05$ ), mean fish densities of low piscivores did not significantly differ icantly lower densities than mangroves (Fig. 4). Notches and reefs did not differ significantly from seagrass beds and mangroves with respect to densities of these 2 groups of piscivores. The covariable distance indicated no significant effect (Table 1). Densities of low piscivores did not differ significantly among any habitat.

Significant effects of habitat type were also observed with respect to different size classes within the piscivore assemblage. For piscivores $>15 \mathrm{~cm}$, densities in seagrass beds were considerably lower than in the other habitat types (Fig. 5). Although there were only significant differences between densities of piscivores of 31 to $45 \mathrm{~cm}$ on mangroves and seagrass beds, (1-way ANCOVA, Table 1), densities were high on the reef, mangroves and notches, whereas lowest densities were observed on seagrass beds (Fig. 5). Likewise, densities of piscivores $>45 \mathrm{~cm}$ were only significantly different between the coral reef and seagrass beds (1-way ANCOVA, p = 0.015), with lowest densities observed on seagrass beds. The covariable distance had a significant effect on densities of both the $>45 \mathrm{~cm}$ and 31 to $45 \mathrm{~cm}$ size classes (Table 1). Small piscivores $(\leq 15 \mathrm{~cm})$ showed a pattern that differed from these 2 larger size classes (Fig. 5). Densities of these small piscivores were significantly higher in notches and
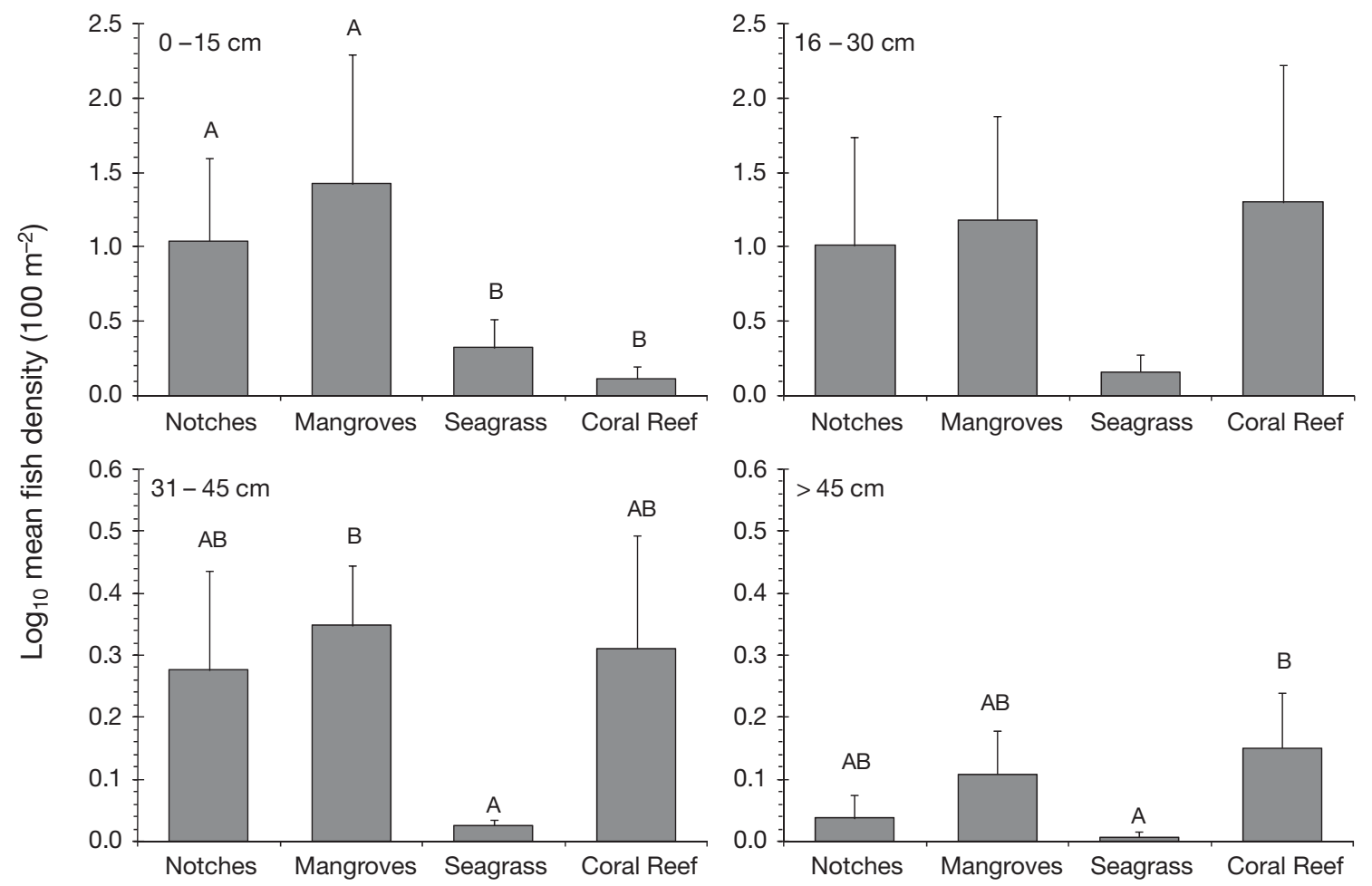

Fig. 5. Mean (+SE) density distribution of the piscivore assemblage in the 4 habitat types during daytime classified into 4 size classes $(0-15 \mathrm{~cm}, 16-30 \mathrm{~cm}, 31-45 \mathrm{~cm},>45 \mathrm{~cm})$. The effect of habitat type (main factor) and distance to the coral reef (covariable) on piscivore density was tested for each size class separately by 1-way analysis of covariance (Table 1). In each graph, different letters among habitat types indicate significantly different fish densities (Sidak's post-hoc comparison, $\mathrm{p}<0.05$ ). Mean fish densities of $16-30 \mathrm{~cm}$ piscivores did not significantly differ 
mangroves than on the reef and seagrass beds (1-way ANCOVA, Table 1). The covariable distance did not have a significant effect on densities of these piscivores, and no significant effect was found for densities of 16 to $30 \mathrm{~cm}$ piscivores.

\section{Distance to the coral reef}

To analyze the effect of distance to the coral reef on the mean density or species richness of the piscivore assemblage at all sites in the gradient (including all habitat types), we performed linear regression analyses on the total piscivore density (day and night), the 3 diet classes and the 4 size classes of piscivores. Only 2 of these regressions showed significant relationships. Both mean density of piscivores $>45 \mathrm{~cm}$ during daytime $\left(\mathrm{p}=0.035, \mathrm{R}^{2}=0.37, \beta=-0.61\right)$ and nighttime $(\mathrm{p}=$ $\left.0.019, R^{2}=0.44, \beta=-0.66\right)$, showed a negative relationship with increasing distance from the coral reef. However, both $\mathrm{R}^{2}$ values were low and explained only a small part of the variation.

\section{Video observations and predation experiments}

Besides visual observations in 10 min time intervals, video observations of removals of 33 tethered fishes could be used to visually identify the predator (Table 2).
Prey removals were recorded on the reef $(n=18)$, seagrass beds $(n=9)$ and mangroves $(n=6)$. Most prey removals were performed by piscivorous fish ( $\mathrm{n}=24$, $73 \%$, Table 2). The remaining prey removals ( $\mathrm{n}=9$, $27 \%$ ) were performed by larger Malacostraca ( $\mathrm{n}=3$, $9 \%)$ or non-piscivorous fish $(\mathrm{n}=6,18 \%)$. All prey removals on the reef were by non-piscivorous fish were observed on the reef, whereas all observed non-piscivore prey removals on seagrass beds $(n=2)$ and mangroves $(\mathrm{n}=1)$ were performed by larger Malacostraca. Aulostomus maculatus (high piscivore, $\mathrm{n}=6$ ), Lutjanus apodus (moderate piscivore, $\mathrm{n}=5$ ), Ocyurus chrysurus (moderate piscivore, $\mathrm{n}=5$ ), Sphoeroides spengleri (low piscivore, $\mathrm{n}=4$ ) were responsible for most prey removals ( $n=20,83 \%$ ) of all observed piscivorous fish species.

Overall comparisons of cumulative survival of tethered fish among sites showed significant differences (generalized Wilcoxon test, $\chi_{\mathrm{df}=1}^{2}=9.80, \mathrm{p}=0.002$ ). Pairwise comparisons showed that survival was significantly highest in the mangroves in the channel (Fig. 6) and lowest on the fringing coral reef site outside of the bay (\#12, Fig. 1). At the end of the 90 min experiments, survival was 0 on the fringing coral reef outside the bay. The seagrass bed and mangrove in the entrance of the bay also showed a relatively low survival after the 90 min period $(<20 \%)$. In contrast to the seagrass bed in the entrance of the bay, survival after the $90 \mathrm{~min}$ period was relatively high in the seagrass bed in the

Table 2. Results of predator identification of successfully recorded prey removals during underwater video recording of predation experiments $(n=33)$. Predator size is expressed as large juvenile, subadult or adult, estimated based on fish coloration pattern and/or estimated in relation to known landmarks in the surrounding (stones, corals, prop roots, seagrass leaves). Values in heading show the location of the site in the investigated gradient (Fig. 1). The first column shows the identified predator species and whether the species is considered a piscivorous fish or a non-piscivorous fish or Malacostraca (see also Appendix 1)

\begin{tabular}{|c|c|c|c|c|c|c|c|c|c|c|c|}
\hline \multirow[t]{3}{*}{ Species } & \multirow{3}{*}{ Common name } & \multirow{3}{*}{$\begin{array}{l}\text { Predator size } \\
\text { indication }\end{array}$} & \multicolumn{8}{|c|}{ No. of recorded prey removals per site } & \multirow{3}{*}{$\begin{array}{c}\text { Total no. of } \\
\text { observations } \\
\left(\mathrm{n}_{\mathrm{tot}}=33\right)\end{array}$} \\
\hline & & & & & Sea & rass & eds & & igro & & \\
\hline & & & 9 & 12 & 8 & 4 & 2 & 7 & 5 & 1 & \\
\hline \multicolumn{12}{|l|}{ Piscivorous } \\
\hline Aulostomus maculatus & Trumpetfish & Adult & & 5 & 1 & & & & & & 6 \\
\hline Cephalopholis fulva & Coney & Subadult & & 1 & & & & & & & 1 \\
\hline Lutjanus apodus & Schoolmaster & $\begin{array}{l}\text { Large juvenile } \\
(\mathrm{n}=3) \text {, Adult }(\mathrm{n}=3)\end{array}$ & & 1 & & & & 1 & & 3 & 5 \\
\hline Lutjanus griseus & Gray snapper & Adult & 1 & & & & & & & & 1 \\
\hline Ocyurus chrysurus & Yellowtail snapper & Large Juvenile & & & & 5 & & & & & 5 \\
\hline Sphoeroides spengleri & Bandtail puffer & Adult & & 4 & & & & & & & 4 \\
\hline Sphyraena barracuda & Barracuda & Subadult & & & & & 1 & & & & 1 \\
\hline Tylosurus crocodilus & Houndfish & Adult & & & & & & & & 1 & 1 \\
\hline \multicolumn{12}{|l|}{ Non-piscivorous } \\
\hline Brachyura & Crab & Adult & & & & & 1 & & & & 1 \\
\hline Stomatopoda & Mantis shrimp & Adult & & & 1 & & & & 1 & & 2 \\
\hline Halichoeres garnoti & Yellowhead wrasse & Adult & & 1 & & & & & & & 1 \\
\hline Scaridae & Parrotfish & Adult & & 1 & & & & & & & 1 \\
\hline Sparisoma aurofrenatum & Redband parrotfish & Adult & 2 & 2 & & & & & & & 4 \\
\hline \multicolumn{3}{|c|}{ Total no. of tethered fish $\left(\mathrm{n}_{\text {tot }}=203\right)$ : } & 21 & 28 & 17 & 17 & 40 & 23 & 16 & 41 & \\
\hline
\end{tabular}




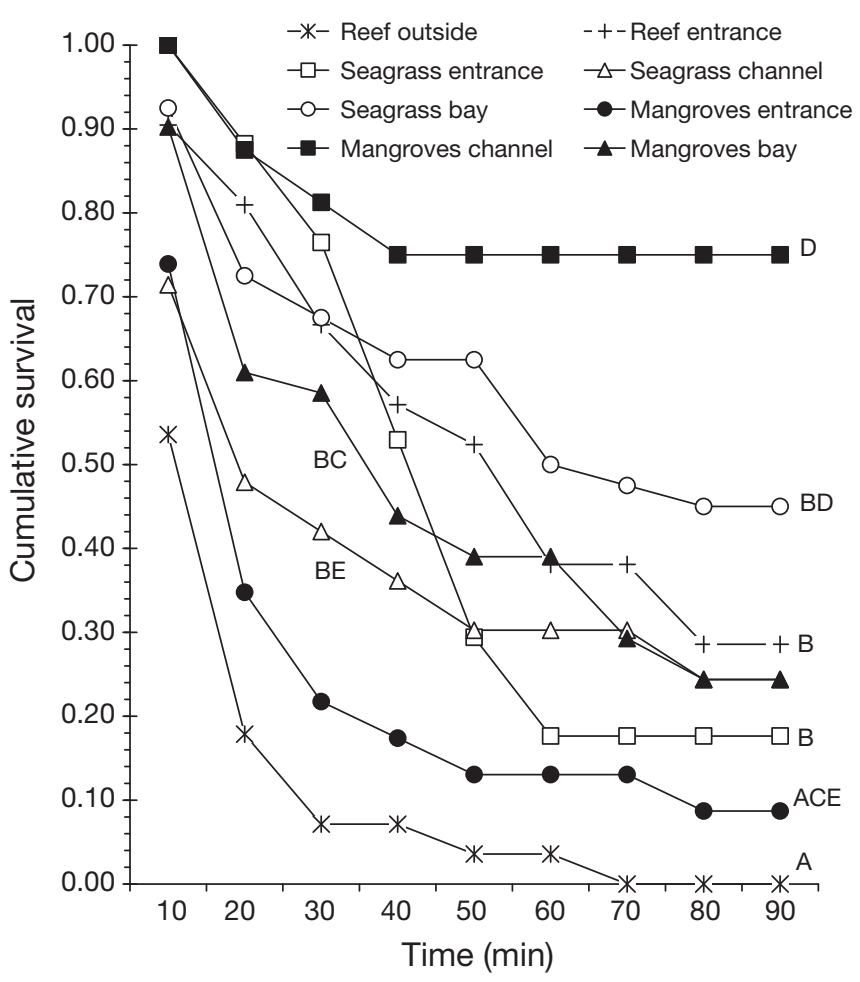

Fig. 6. Relative survival of tethered, recently settled juvenile Haemulon flavolineatum in predation experiments in 4 habitat types spread over 8 sites (see 'Materials and methods' and Fig. 1). Different letters indicate statistical differences obtained by survival analysis (generalized Wilcoxon post-hoc comparisons, $\mathrm{p}<0.05$ )

centre of the bay. For the fringing coral reef outside the bay, the mangrove in the entrance and the seagrass bed in the channel, survival dropped very fast and was below $50 \%$ after 20 min. On the contrary, cumulative survival in the seagrass bed in the centre of the bay dropped below $50 \%$ only after $70 \mathrm{~min}$. Survival at the mangrove site in the channel showed a pattern different from the other sites, remaining high (75\%) and not changing anymore after $40 \mathrm{~min}$.

For 8 sites data for predation experiments as well as data for total piscivore density were available. ANCOVA that investigated the effect of habitat type and distance to the coral reef (as a covariable) on survival of tethered fish and mean total piscivore density, showed only a significant effect of habitat type on mean total piscivore fish density (2-way ANCOVA, Table 1).

\section{DISCUSSION}

Observations in the present study showed that high densities of piscivore assemblages occur on both the coral reef and in back-reef habitats. Although species assemblages differed greatly, these habitats harboured species for which fish is an important part of their diet (in the present study defined as highly and moderately specialized piscivores). Back-reef habitats were characterized by high densities of piscivore species that most likely used Spanish Water Bay during their settlement and early juvenile life phase (e.g. Lutjanus griseus, L. apodus, Sphyraena barracuda, defined by Nagelkerken et al. 2000a), complemented with reefassociated visiting piscivores (e.g. Carangoides ruber, Caranx latus, Scorpaena plumieri). Conversely, the reef was characterized by high densities of typical reef-associated piscivores (e.g. Aulostomus maculatus, Cephalopholis cruentatus, C. fulva), complemented with (sub)adults of piscivores that most likely used the bay as a juvenile habitat and had migrated to the coral reef (e.g. Lutjanus apodus, Ocyurus chrysurus).

Predation experiments illustrate that the presence of piscivores in both reef and back-reef habitats results in reduced survival of small juvenile fish. Low survival was observed on the coral reef as well as in various habitats located in the bay. Although predation experiments by means of tethered fish do not resemble a natural situation, it is reasonable to assume that the observed piscivores in reality contribute to reduced survival of juvenile fish (see also next paragraph). These observations therefore support the hypothesis that back-reef habitats harbour important piscivore assemblages (Baker \& Sheaves 2005, Chittaro et al. 2005, Baker \& Sheaves 2006, Baker \& Sheaves 2007).

Despite the presence of considerable piscivore assemblages in both reef and back-reef habitats, there was a clear influence of habitat type on the structure and density of piscivore assemblages in the studied habitats. Total piscivore densities were highest in habitats with a high structural complexity. This was most evident in the mangroves, which are characterized by a dense system of submerged prop roots, providing shelter places for smaller fishes. Nagelkerken et al. (2000a) showed high fish densities in structurally complex habitats (mangroves and boulders in notches) in Spanish Water Bay, indicating that fishes concentrate in these habitats. Likewise, the present study also shows a concentration of piscivorous fishes in these habitats, indicating the habitats also provide a shelter function for piscivores.

As opposed to the coral reef, notches and mangroves, the lowest total density of piscivores was observed on seagrass beds. When only focusing on total piscivore densities, this suggests that seagrass beds are the safest habitat for small juvenile fish. However, there was no consistent pattern of higher survival of tethered fish on seagrass beds compared to the other habitats. Only survival of tethered fish at the seagrass bed located deep inside the bay was relatively high, as opposed to those located in the channel and at the bay 
entrance. The low density of piscivores on seagrass beds is therefore likely to be confounded by site effects (e.g. the distance to the coral reef or the adjacent habitat type) and significant predation on small juvenile fish may therefore still occur in seagrass beds. Predation pressure on some of the seagrass beds was partly illustrated by video-recorded removals of tethered fish by Ocyurus chrysurus.

It is not merely total piscivore density that determines predation risk. The diet and size of the piscivores may influence predation risk in a habitat as well. Larger predators and predators with a strict piscivore diet are likely to be very efficient predators on small juvenile fish (Scharf et al. 2000, Kulbicki et al. 2005). However, all studied habitats were dominated by moderately specialized piscivores and showed a comparable density distribution of the distinguished diet types, in which all seagrass beds were characterized by low overall densities. It is therefore unlikely that habitat type had a strong influence on the structure of the piscivore assemblages based on diet.

On the contrary, a clear pattern could be distinguished in the distribution of size classes of the piscivore assemblage in each habitat. The piscivore assemblages in seagrass beds, notches and mangroves were characterized by high densities of small piscivores ( 0 to $15 \mathrm{~cm}$ ). As has been suggested above, a large part of the piscivore assemblage in the bay is likely to consist of larger juveniles and subadults of fish species that used habitats in Spanish Water Bay as a juvenile habitat. Various species that are considered as piscivores in the present study have also been categorized as nursery species before (i.e. reef fish species that predominantly use seagrass beds and mangroves as a juvenile habitat; Nagelkerken et al. 2000a). Although these individuals are relatively small, several of these species are likely to feed on small, recently settled juvenile fish. Lutjanus apodus and Ocyurus chrysurus $<15 \mathrm{~cm}$ feed partly on fish (Cocheret de la Morinière et al. 2003a), and video analyses in the present study showed that larger juveniles ( 10 to $20 \mathrm{~cm}$ TL) of these species actually removed tethered fish. Also, smaller Sphyraena barracuda ( $<15 \mathrm{~cm} \mathrm{TL})$, a piscivore that occurs in relatively high densities in the bay, feed predominantly on fish (Lugendo et al. 2006). A large part of the piscivore assemblage in back-reef habitats may therefore consist of species that use these habitats originally as settlement and early juvenile habitats and eventually contribute to predation pressure in these habitats in later life stages (Baker \& Sheaves 2005).

There was no clear influence of distance to the coral reef/entrance of Spanish Water Bay on piscivore density, species richness and prey fish survival. However, the species structure of the piscivore assemblage greatly changed along the gradient. Various larger reef-associated predators were observed in the entrance of the bay (e.g. Carangoides crysos, Carangoides ruber, Caranx latus, Cephalopholis cruentatus, Synodus intermedius, Oligoplites saurus). Some of these species occasionally visited habitats located in the center of Spanish Water Bay (i.e. Caranx latus, Oligoplites saurus, Appendix 1). Additionally, a video observation showed that the reef-associated Aulostomus maculatus consumed a tethered fish on the seagrass bed in the entrance of the bay (Table 2). This indicates that visiting piscivores enter the entrance area and join the local piscivore assemblage (Dorenbosch et al. 2007, Valentine et al. 2007). Larger piscivores are assumed to be more efficient predators on small juvenile fish than smaller predators (Scharf et al. 2000, Kulbicki et al. 2005). Since most of the visiting piscivores are larger (i.e. $>15 \mathrm{~cm}$ ) and have a strict fish diet, it can be inferred that they contribute significantly to prey removal in the seagrass bed and mangroves in the entrance area of the bay, hereby resembling the pattern of prey removal on the fringing coral reef.

\section{Limitations of the study}

A priori classification of the piscivore assemblage into diet classes was based on data in the literature and was not evaluated in the study area for most species. For fish species that have fish only as a minor part of their diet (in this study defined as low piscivores), their contribution to predation pressure in a specific habitat can therefore be debated. However, for some species that do not entirely depend on fish in their diet, such as Sphoeroides spengleri and larger juveniles of Lutjanus apodus and Ocyurus chrysurus, video recording confirmed that these species prey on small juvenile fish as part of their diet. Settlement of coral reef fishes occurs in clear peaks that subsequently result in temporarily high densities of small juveniles. It is therefore likely that fish species with a broad diet that includes fish, to some extent, actually prey on small juvenile fish when this is a widely available food source, for example, after settlement peaks.

Although video observations showed that most successful prey removals could actually be ascribed to piscivorous fishes $(n=24)$, there were also some prey removals $(n=9)$ by Malacostraca and fishes that were not considered as real piscivores (such as Scaridae). It is therefore likely that prey removals by non-piscivorous fishes resulted in some overestimation of predation pressure. Since the observed prey removals by non-piscivorous fish were considerably higher on the reef, this overestimation was most likely strongest on the coral reef. With respect to this overestimation of 
predation pressure, the following can be concluded. (1) Prey removal of tethered fish by piscivorous fish was demonstrated unambiguously in all habitats by video observations. Based on these observations it is very likely that piscivorous fish contributed most to removal of tethered fish in all habitats. (2) Overestimation of predation pressure would most likely affect observed predation pressure on the coral reef, which may be lower than the data suggest. This hypothesized lower predation pressure on the coral reef would only decrease the observed difference between predation pressure on the coral reef and back-reef habitats by piscivorous fish. In our opinion, a possible overestimation of predation pressure in habitats, in particular on the coral reef, therefore does not strongly undermine the major finding of the present study: piscivore assemblages in various back-reef habitats contribute to significant mortality of small juvenile fish in some of these habitats.

Various studies suggest predation may be high during dusk, dawn or at night (McFarland 1991, Danilowicz \& Sale 1999) and that piscivore fish assemblages change greatly during nighttime (Unsworth et al. 2007). Consequently, this could result in different piscivore assemblages between day and night in the habitats and may undermine the daytime observations of the present study. However, the survey conducted at night also showed a significant effect of habitat type on the piscivore assemblage. The coral reef showed high densities of piscivores comparable to the densities observed during the day. Mangroves showed considerably lower densities at night, indicating these fishes leave this habitat during nighttime. Nagelkerken et al. (2000b) showed a similar observation and suggested fishes that shelter in mangroves during day feed in adjacent habitats in the Spanish Water Bay at night. Data in the present study suggest this is also valid for the piscivore assemblage in mangroves. Since the total surface of mangroves in Spanish Water Bay is only small in relation to the total surface of seagrass beds (Nagelkerken et al. 2000a), the number of piscivores that shelter in mangroves during day is distributed over the extensive seagrass beds (the most adjacent habitat), which subsequently results in a low piscivore density. As a result, it can be concluded that total piscivore density in mangroves greatly declines at night, but that the low piscivore density observed during the day on seagrass beds does not greatly change during the night.

\section{Piscivore assemblages and nursery function}

It is assumed that back-reef habitats are important nurseries for coral reef fishes, as a result of increased food availability and/or reduced predation pressure.
Dahlgren \& Eggleston (2000) suggested that for juvenile fish in these back-reef habitats a tradeoff exists between minimizing predation risk and maximizing growth. The observations in the present study show that back-reef habitats used by juvenile fish have significant piscivore assemblages that may result in a high predation pressure, possibly even comparable with that on the reef. In line with results of other studies (Baker \& Sheaves 2005, Chittaro et al. 2005, Baker \& Sheaves 2006, Baker \& Sheaves 2007), these piscivore assemblages in back-reef habitats may be a determining factor for the importance of the nursery function of these habitats.

Mangroves are in general considered an important nursery habitat because the structural complexity provides efficient shelter for small juvenile fish (Laegdsgaard \& Johnson 2001). The present study shows that this is not always the case. Mangroves with a high structural complexity concentrated piscivorous fishes, which at 2 sites could clearly be related to reduced survival of tethered fish. However, the present study also showed significant variability in piscivore assemblages in mangroves. There was a clear spatial effect present for total piscivore density at the various mangrove sites in Spanish Water Bay, while tethering experiments in the channel mangroves showed considerably higher survival in comparison with the other 2 investigated mangrove sites. A similar pattern of variability was found in the seagrass beds. In general, the data of the present study showed low total piscivore densities in all sampled seagrass beds, but high survival of tethered fishes was only observed in the seagrass bed located in the centre of Spanish Water Bay. This contradicts observations of relatively low survival of tethered fish in seagrass beds in the entrance and channel of the bay. These observations suggest that survival as a result of predation in back-reef habitats is confounded by sitespecific effects, e.g. the distance to the coral reef or the type of adjacent habitat.

Still, of various back-reef habitats, total piscivore densities were only low in seagrass beds, and at least 1 seagrass bed located away from the reef showed relatively high survival. Depending on the configuration of habitats within the seascape, some seagrass beds may therefore be an attractive habitat for recently settled small juvenile fish to spend their early juvenile life stage, which is in line with observations of directed settlement on specific seagrass sites in a gradient of habitats (Watson et al. 2002, Pollux et al. 2007). Furthermore, it should be considered that the total surface area of seagrass beds is much larger than that of mangroves, notches, and reefs in Spanish Water Bay (see Nagelkerken et al. 2000a), while the bay area, with its safer seagrass habitats, has a much larger surface area 
than the channel and entrance of the embayment. Therefore, for large areas within Spanish Water Bay predation risk is expected to be relatively low.

The present study shows the presence of significant piscivore assemblages on both the coral reef and in back-reef habitats in the investigated gradient. Both areas encompass high densities of piscivores that result in a relatively high predation risk, as indicated by predation experiments. Immigration of visiting piscivores from the coral reef and high densities of larger resident piscivorous nursery species present in structure-rich habitats in the bay may explain this observation. However, of all habitat types in the investigated gradient, seagrass beds showed the lowest piscivore densities, while 1 seagrass bed away from the coral reef also indicated higher survival of tethered fish than in other habitats. Depending on the seascape configuration of habitats (i.e. distance to the coral reef and the presence of other habitats that concentrate predators), this suggests that in a Caribbean shallowwater seascape (such as the sheltered marine bay in the present study) some seagrass beds may be safe habitats for small juvenile coral reef fishes.

Acknowledgements. This study was funded by the Netherlands Organization for Scientific Research NWO as part of a VIDI grant to I.N. A.d.G. was funded by a grant from the SchureBeijerinck-Popping Fonds. We thank the management and staff of the Caribbean Research and Management of Biodiversity Institute (CARMABI) in Curaçao for the use of their facilities and for their support. We are also grateful to S. Wartenbergh for her help in the field. J. Aben and S.E. Wendelaar-Bonga contributed to earlier versions of the manuscript. This is publication No. 499 of the Centre for Wetland Ecology. The research of the present study was in accordance with the local institutional guidelines concerning the use of animals in research.

\section{LITERATURE CITED}

Almany GR (2004) Does increased habitat complexity reduce predation and competition in coral reef fish assemblages? Oikos 106:275-284

Almany GR, Webster MS (2006) The predation gauntlet: early post-settlement mortality in reef fishes. Coral Reefs 25: 19-22

Arvedlund M, Takemura A (2006) The importance of chemical environmental cues for juvenile Lethrinus nebulosus Forsskal (Lethrinidae, Teleostei) when settling into their first benthic habitat. J Exp Mar Biol Ecol 338:112-122

Baker R, Sheaves M (2005) Redefining the piscivore assemblages of shallow estuarine nursery habitats. Mar Ecol Prog Ser 291:197-213

Baker R, Sheaves M (2006) Visual surveys reveal high densities of large piscivores in shallow estuarine nurseries. Mar Ecol Prog Ser 323:75-82

Baker R, Sheaves M (2007) Shallow-water refuge paradigm: conflicting evidence from tethering experiments in a tropical estuary. Mar Ecol Prog Ser 349:13-22

Beck MW, Heck KL, Able KW, Childers DL and others (2001) The identification, conservation, and management of estuarine and marine nurseries for fish and invertebrates.
Bioscience 51:633-641

Beets J (1997) Effects of a predatory fish on the recruitment and abundance of Caribbean coral reef fishes. Mar Ecol Prog Ser 148:11-21

Blaber SJM (2000) Tropical estuarine fishes: ecology, exploitation, and conservation. Fish and aquatic resources series 7, Blackwell Science, Oxford

Chittaro PM, Usseglio P, Sale PF (2005) Variation in fish density, assemblage composition and relative rates of predation among mangrove, seagrass and coral reef habitats. Environ Biol Fishes 72:175-187

Cocheret de la Morinière E, Pollux BJA, Nagelkerken I, van der Velde G (2002) Post-settlement life cycle migration patterns and habitat preference of coral reef fish that use seagrass and mangrove habitats as nurseries. Estuar Coast Shelf Sci 55:309-321

Cocheret de la Morinière E, Pollux BJA, Nagelkerken I, van der Velde G (2003a) Diet shifts of Caribbean grunts (Haemulidae) and snappers (Lutjanidae) and the relation with nursery-to-coral reef migrations. Estuar Coast Shelf Sci 57:1079-1089

Cocheret de la Morinière E, Pollux BJA, Nagelkerken I, Hemminga MA, Huiskes AHL, van der Velde G (2003b) Ontogenetic dietary changes of coral reef fishes in the mangrove-seagrass-reef continuum: stable isotopes and gut-content analysis. Mar Ecol Prog Ser 246:279-289

Dahlgren CP, Eggleston DB (2000) Ecological processes underlying ontogenetic habitat shifts in a coral reef fish. Ecology 81:2227-2240

> Danilowicz BS, Sale PF (1999) Relative intensity of predation of the French grunt, Haemulon flavolineatum, during diurnal, dusk and nocturnal periods on a coral reef. Mar Biol 133:337-343

> Dorenbosch M, van Riel MC, Nagelkerken I, van der Velde G (2004) The relationship of reef fish densities to the proximity of mangrove and seagrass nurseries. Estuar Coast Shelf Sci 60:37-48

> Dorenbosch M, Verberk WCEP, Nagelkerken I, van der Velde G (2007) Influence of habitat configuration on connectivity between fish assemblages of Caribbean seagrass beds, mangroves and coral reefs. Mar Ecol Prog Ser 334:103-116

Duarte LO, Garcia CB (1999) Diet of the mutton snapper Lutjanus analis (Cuvier) from the Gulf of Salamanca, Colombia, Caribbean Sea. Bull Mar Sci 65:453-465

> Eggleston DB, Lipcius RN, Grover JJ (1997) Predator and shelter-size effects on coral reef fish and spiny lobster prey. Mar Ecol Prog Ser 149:43-59

Eggleston DB, Dahlgren CP, Johnson EG (2004) Fish density, diversity, and size-structure within multiple back reef habitats of Key West National Wildlife Refuge. Bull Mar Sci 75:175-204

Floeter J, Temming A (2005) Analysis of prey size preference of North Sea whiting, saithe, and grey gurnard. ICES J Mar Sci 62:897-907

Froese R, Pauly D (2005) Editors. FishBase. World Wide Web electronic publication. www.fishbase.org, version (02/2005).

Gagliano M, McCormick MI (2007) Compensating in the wild: Is flexible growth the key to early juvenile survival? Oikos 116:111-120

> Hixon MA, Jones GP (2005) Competition, predation, and density-dependent mortality in demersal marine fishes. Ecology 86:2847-2859

> Hoey AS, McCormick MI (2004) Selective predation for low body condition at the larval-juvenile transition of a coral reef fish. Oecologia 139:23-29

Holmes TH, McCormick MI (2006) Location influences size- 
selective predation on newly settled reef fish. Mar Ecol Prog Ser 317:203-209

Kamukuru AT, Mgaya YD (2004) The food and feeding habits of blackspot snapper, Lutjanus fulviflamma (Pisces: Lutjanidae) in shallow waters of Mafia Island, Tanzania. Afr J Ecol 42:49-58

Kulbicki M, Bozec YM, Labrosse P, Letourneur Y, Mou-Tham G, Wantiez L (2005) Diet composition of carnivorous fishes from coral reef lagoons of New Caledonia. Aquat Living Resour 18:231-250

Laegdsgaard P, Johnson C (2001) Why do juvenile fish utilise mangrove habitats? J Exp Mar Biol Ecol 257:229-253

Lugendo BR, Nagelkerken I, van der Velde G, Mgaya YD (2006) The importance of mangroves, mud and sand flats, and seagrass beds as feeding areas for juvenile fishes in Chwaka Bay, Zanzibar: gut content and stable isotope analyses. J Fish Biol 69:1639-1661

Marnane MJ, Bellwood DR (2002) Diet and nocturnal foraging in cardinalfishes (Apogonidae) at One Tree Reef, Great Barrier Reef, Australia. Mar Ecol Prog Ser 231: 261-268

McAleece N (1997) BioDiversity Pro Beta 2. The Natural History Museum London/Scottish Association for Marine Science, London

> McCormick MI, Hoey AS (2004) Larval growth history determines juvenile growth and survival in a tropical marine fish. Oikos 106:225-242

McFarland WN (1991) The visual world of coral reef fishes. In: Sale PF (ed) The ecology of fishes on coral reefs. Academic Press, San Diego, CA, p 16-38

Mittelbach GG, Chesson PL (1987) Predation risk: indirect effects on fish populations. In: Kerfoot WC, Sih A (eds) Predation. Direct and indirect impacts on aquatic communities. University Press of New England, Hanover-London, p 313-332

Nagelkerken I, Dorenbosch M, Verberk WCEP, Cocheret de la Morinière E, van der Velde G (2000a) Importance of shallow-water biotopes of a Caribbean bay for juvenile coral reef fishes: patterns in biotope association, community structure and spatial distribution. Mar Ecol Prog Ser 202:175-192

Nagelkerken I, Dorenbosch M, Verberk WCEP, Cocheret de la Morinière E, van der Velde G (2000b) Day-night shifts

Editorial responsibility: John Choat,

Townsville, Queensland, Australia of fishes between shallow-water biotopes of a Caribbean bay, with emphasis on the nocturnal feeding of Haemulidae and Lutjanidae. Mar Ecol Prog Ser 194:55-64

Nakamura Y, Sano M (2004) Is there really lower predation risk for juvenile fishes in a seagrass bed compared with an adjacent coral area? Bull Mar Sci 74:477-482

Pollux BJA, Verberk WCEP, Dorenbosch M, Cocheret de le Morinière E, Nagelkerken I, van der Velde G (2007) Habitat selection during settlement of three Caribbean coral reef fishes: Indications for directed settlement to seagrass beds and mangroves. Limnol Oceanogr 52:903-907

Rooker JR (1995) Feeding ecology of the Schoolmaster snapper, Lutjanus apodus (Walbaum), from southwestern Puerto-Rico. Bull Mar Sci 56:881-894

Scharf FS, Juanes F, Rountree RA (2000) Predator size-prey size relationships of marine fish predators: interspecific variation and effects of ontogeny and body size on trophicniche breadth. Mar Ecol Prog Ser 208:229-248

Shulman MJ (1985) Recruitment of coral reef fishes: effects of distribution of predators and shelter. Ecology 66: 1056-1066

St John J (1999) Ontogenetic changes in the diet of the coral reef grouper Plectropomus leopardus (Serranidae): patterns in taxa, size and habitat of prey. Mar Ecol Prog Ser 180:233-246

Unsworth RKF, Wylie E, Bell JJ, Smith DJ (2007) Diel trophic structuring of seagrass bed fish assemblages in the Wakatobi Marine National Park, Indonesia. Estuar Coast Shelf Sci 72:81-88

- Valentine JF, Heck KL, Blackmon D, Goecker ME and others (2007) Food web interactions along seagrass-coral reef boundaries: effects of piscivore reductions on crosshabitat energy exchange. Mar Ecol Prog Ser 333:37-50

Verweij MC, Nagelkerken I, Hans I, Ruseler SM, Mason PRD (2008) Seagrass nurseries contribute to coral reef fish populations. Limnol Oceanogr 53:1540-1547

Vigliola L, Meekan MG (2002) Size at hatching and planktonic growth determine post-settlement survivorship of a coral reef fish. Oecologia 131:89-93

Watson M, Munro JL, Gell FR (2002) Settlement, movement and early juvenile mortality of the yellowtail snapper Ocyurus chrysurus. Mar Ecol Prog Ser 237:247-256

Submitted: May 26, 2008; Accepted: December 17, 2008 Proofs received from author(s): March 19, 2009 


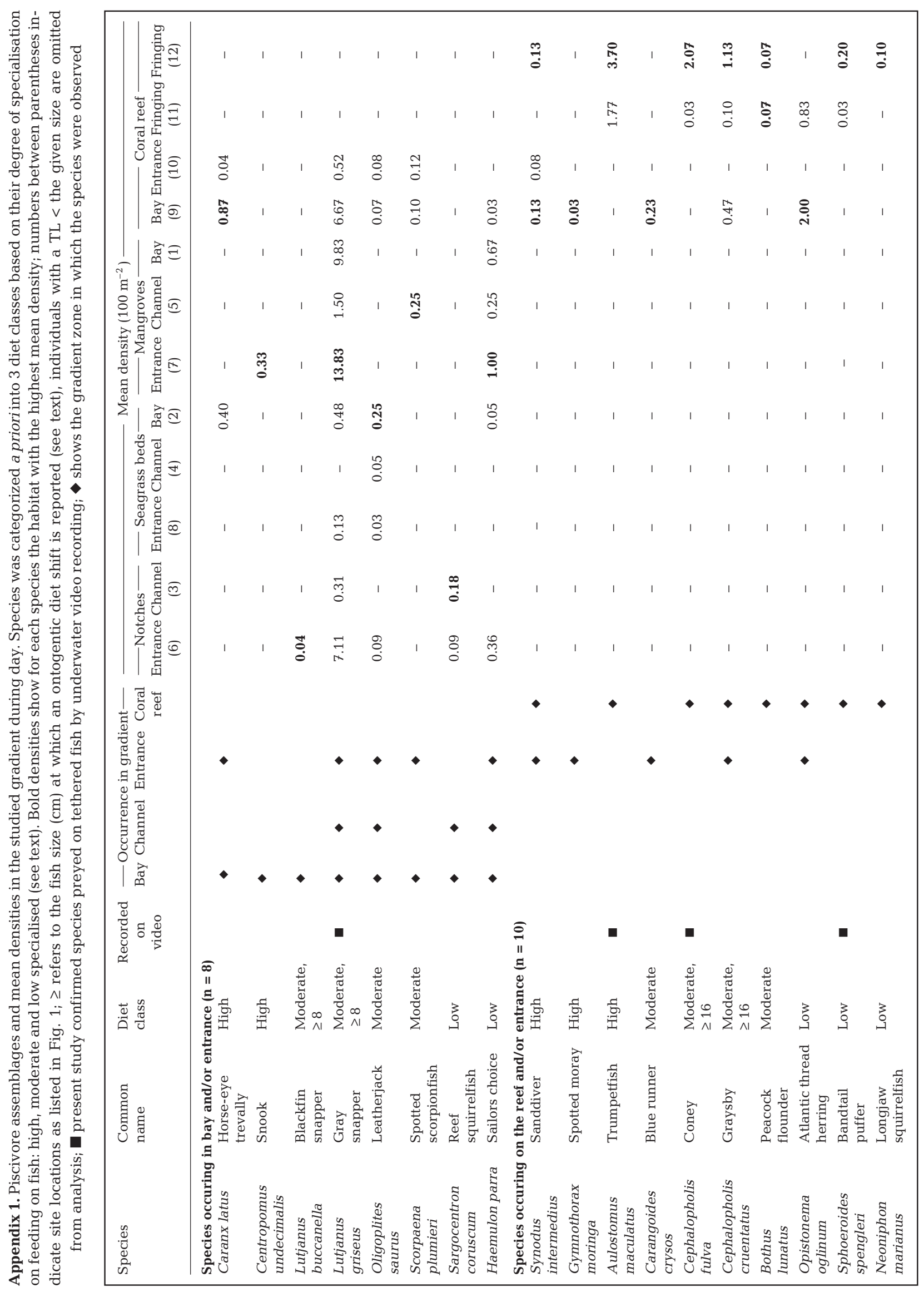




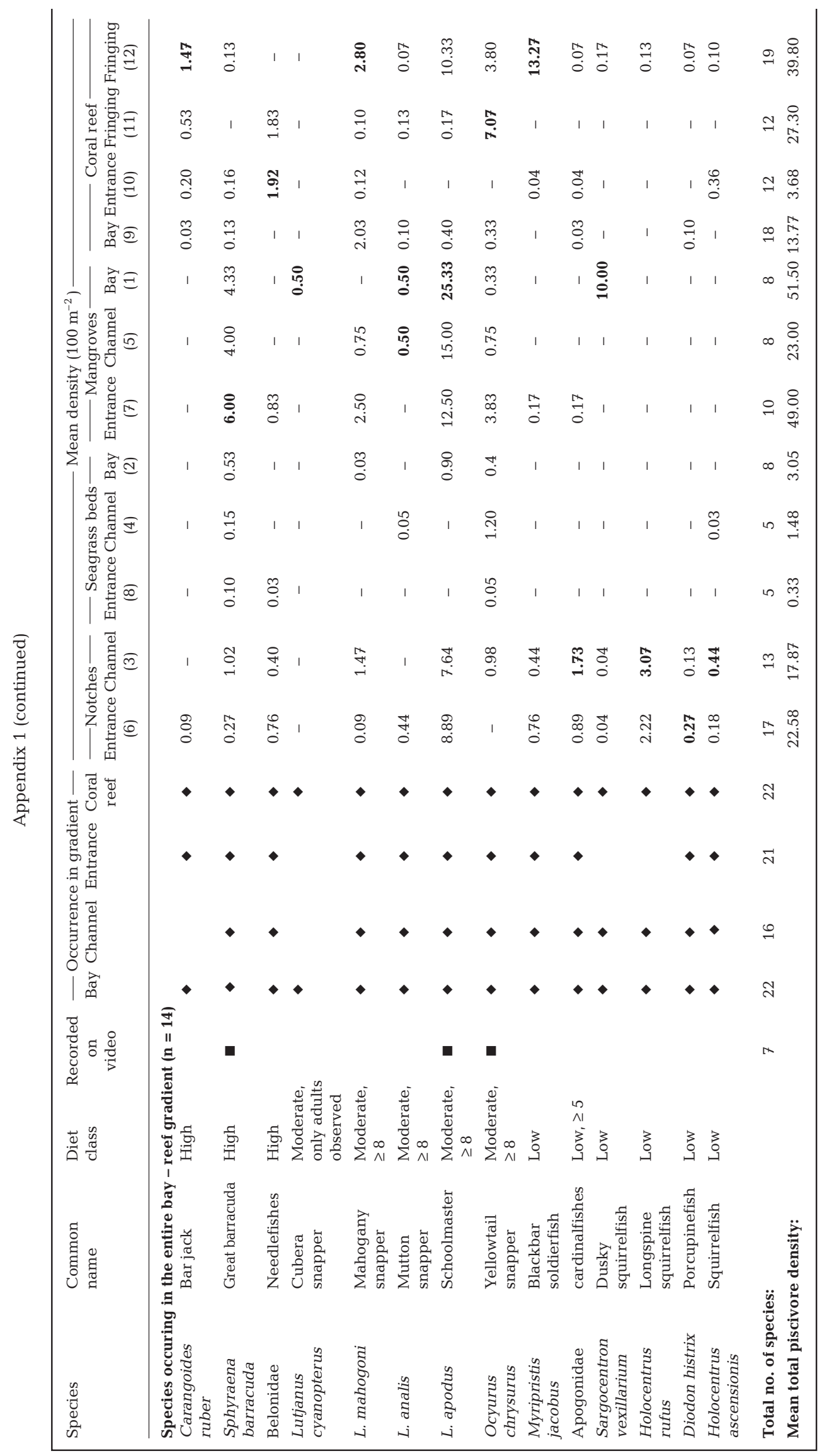

